\title{
An Analysis of Language Code Used by the Cross- Married Couples, Banjarese- Javanese Ethnics: A Case Study in South Kalimantan Province, Indonesia
}

\author{
Supiani \\ English Department, Teachers Training Faculty, Islamic University of Kalimantan Banjarmasin \\ South Kalimantan Province, Indonesia \\ E-mail: supi_rus@yahoo.com
}

Doi:10.7575/aiac.alls.v.7n.4p.139

URL: http://dx.doi.org/10.7575/aiac.alls.v.7n.4p.139
Received: 02/04/2016

Accepted: 07/06/2016

\begin{abstract}
This research aims to describe the use of language code applied by the participants and to find out the factors influencing the choice of language codes. This research is qualitative research that describe the use of language code in the cross married couples. The data are taken from the discourses about language code phenomena dealing with the cross- married couples, Banjarese- Javanese ethnics in Tanah Laut regency South Kalimantan, Indonesia. The conversations occur in the family and social life such as between a husband and a wife, a father and his son/daughter, a mother and her son/daughter, a husband and his friends, a wife and her neighbor, and so on. There are 23 data observed and recoded by the researcher based on a certain criteria. Tanah Laut regency is chosen as a purposive sample where this regency has many different ethnics so that they do cross cultural marriage for example between Banjarese- Javanese ethnics. Findings reveal that mostly the cross married couple used code mixing and code switching in their conversation of daily activities. Code mixing is uttered by Javanese father or mother to their children. Mixed codes are used namely Banjarese+Javanese+Indonesian. Meanwhile, code switching occurs when there is another factor or a new participant who join in the discourse. The codes change from Banjarese to Indonesian codes or Javanese to Indonesian codes due to new participant who involve himself/herself in the dialogue. The influential factors are situational factors, the environment (neighborhood), relative status, and ethnicity.
\end{abstract}

Keywords: Language codes, Cross- married couples, Banjarese and Javanese ethics, Dialects

\section{Introduction}

People use language to communicate in their everyday social interactions. Thus, language becomes an important medium of communication. In communication, language makes people easier to express their thoughts, feelings, experiences, and so on. Wardhaugh explains that language allows people to say things to each other and express communicative needs (1998). In short, language is constantly used by humans in their everyday life. In all human activities, the language use has an important correlation with the factors outside of it. People commonly use language in accordance with social structure and value system of society. The internal and external differences in human societies such as sex, age, class, occupation, geographical origin and so on, also influence their language. Most of us speak differently to different people or to the same people in different circumstances. One of the interdisciplinary sciences, which study the relation between sociology and linguistics, is called sociolinguistics.

The use of different languages in different islands or areas causes language varieties or linguistic diversity. In a social interaction, the contact between one language and other languages may happen. Bilingualism and multilingualism then occur. According to Lado (in Asril Marjohan, 1976) bilingualism is: "popularly the ability to speak two languages equally or most equally well, it is used technically to refer to any degree of knowledge of two knowledge by the same person" (p.124). Then multilingualism simply means a comprehension of more than two languages by an individual or a speech community.

As an archipelago's nation, Indonesia has composition of the various ethnic groups that settle such as Banjarese, Javanese, Dayaknese, Bataknese, Bugisnese and so on. Of course, every ethnic possesses its own indigenous languages that come into contact with each other. Therefore, these have led Indonesia to be not only multicultural but also multilingual ethnic groups. Here, the cross-married couples, Banjarese- Javanese ethnic in Tanah Laut regency, South Kalimantan, Indonesia for example, constitutes an ethnic group of having a different cultural background and language, which has become a bilingual and multilingual community of linguistic groups.

In a bilingual and multilingual situation, language variation may occur. But Pier Paolo Giglioli (1974) indicates that language variation also occurs in a monolingual situation. It is common that the cross- married couples use more than one variety, switch and even mix those varieties. A variety or code refers to any kind of language, includes dialect, accent, sociolect, style or register (Trudgill, 1992). The setting of this research is in Tanah Laut regency South Kalimantan, Indonesia, it is known that many ethnics come to this regency and one of them is a Javanese ethnic. A 
Javanese ethnic comes to this regency for the purpose of following transmigration program, looking for job, or being invited by the Banjarese husband and so on. Since they have lived and worked there, and finally they did an intercultural marriage with Banjarese ethnics or natives of Tanah Laut regency South Kalimantan. He or she often interacts and communicates with his or her couple, so contact with another language occurs. As Cross- Married Couple, they did not only use Banjarese language but also they use Javanese language and even Indonesian language. But sometimes the mixing and switching languages happen in their conversations.

The cross- married couples, who used more than one code to interact for many occasions would face a problem. They should choose which code is appropriate used in a certain occasion. Language choice is usually connected with domain. It happened because as a constellation of topic, setting, and participant, domains determine a certain code that should be used in order to make a conversation runs well.

Fishman mentions five domains, which can be identified in many communities; they are family, friendship, religion, and employment (in Holmes, 1992). Meanwhile, every code or variety chosen by an individual or a speech community has social meanings, to show social distances, status, formality and function of the interaction (Holmes, 1992). The cross- married couples, Banjarese- Javanese ethnic in this research should choose code which is appropriate when used in a certain occasion. There are certain factors in this research that determine the choice of codes. Furthermore, every code chosen by them has social meanings. Many sociolinguists argue that the existence of varieties spoken by the member of society gives us a clue that there is correlation between linguistic diversities and social backgrounds. It is supported by Peter Trudgill's statement that: "the internal differentiation of human societies is reflected in their language" (1974). There are some forms of social differentiation, such as social class, age, race, religion, and others. In this research, most of the participants are members of family; there are differences between them that perform linguistic varieties in their conversations. The choice of certain codes is influenced by their family or ethnic background.

Therefore, the researcher is interested in exploring language codes that are used by the cross- married couples, Banjarese- Javanese ethnic group in Tanah Laut regency, South Kalimantan province. In this research, there are interesting phenomena describing about the community of the cross- married couples, Banjarese- Javanese ethnic group who have lived and worked in Tanah Laut regency South Kalimantan. As intercultural marriage absolutely they face many problems in interacting to their family or relatives and society.

\section{Method}

It is a kind of qualitative research. According to Bogdam and Taylor in Moleong (2000), qualitative research is a research, which produces descriptive data consisting of written or spoken words and so behavior. It means that this research describes systematically the mutual interrelationship between language and society including the norms of language use: when and for what purpose does somebody speak what kind of language or what variety with whom (Routledge Dictionary of Language and Linguistic, 1996) accurately and factually.

\subsection{Sample and Data Collection}

A sample is "a portion or subset of a larger group called population, while population is the universe to be sampled" (Fink 1995: 1). The samples of the research are 23 discourses in "the cross-married couples, Banjarese-Javanese ethnics in Tanah Laut regency South Kalimantan" about language code relating to the participants. The sample is chosen through purposive sampling technique. Through this technique, the samples based on a certain criteria dealing with the purpose of the research (Singarimbun, 1982).

In collecting data, the researcher follow three steps. Firstly, the researcher employs on the use of language code and influential factors that are reported in the observation, and questionnaire. Secondly, the researcher records the conversations of the couples, Banjarese- Javanese ethnics using a tape recorder. This recording technique is done secretly without being known by the participants. It is done so that the speech event could happen naturally. And lastly, the researcher makes transcriptions of all those conversations and decides which discourse that can be used as the data of the research.

\section{Findings and Discussion}

This research is conducted in two stages. Firstly, the data are investigated from the use of each codes occurring in some domains of cross married couples, Banjarese- Javanese ethnic in Tanah-Laut regency South Kalimantan. Secondly, the data are analyzed based on the factors influencing the choice of codes.

\subsection{The Use of Each Code Used by the Cross Married Couple, Banjarese- Javanese Ethnic Group in Tanah Laut Regency South Kalimantan}

This part is to determine the use of each code used by cross married couples, Banjarese- Javanese ethnic in Tanah Laut regency South Kalimantan, through various domains. It is helpful to use some domains that related to certain topics, role relation (participants), and locales (locations). The domains are family, neighborhood, and friendship. Sridhar in Mckay and Hornberger stated that the participant, the setting, and the topic are a helpful to study the distribution of varieties/codes occurring in a speech community. Those are a framework to analyze the linguistic choices available to the multilingual and their reasons for choosing one code from the others (1996). Generally code switching and code mixing happen in a multilingual society in using two languages or more (Sumarsih, et al, 2014) 


\subsubsection{Family domain}

Family domain is the unity of certain participants, certain locations and certain topics. The participants in this domain are the members of family and the relatives. Members of the speech, judge that the use of that variety, and not the others, is appropriate to the domain (Downes, 1984). The conversation takes place at home. There are various topics related to their life (it can be about daily's menu for breakfast, advising family member, etc). This domain occurs two codes, code switching and code mixing. Here is the following data:

a. Code mixing

Daughter

Mother (Javanese)

Daughter

Mother
:Abah nengdi, ma? (Where is dad, mam?)

:Aku gak ngerti Vi, mungkin diadah embahmu (I do not know Vi. Perhaps your dad is in your grandfather's house)

:Baapa kesana? (What will he do there?)

:Ada nang ditakunakan (He will ask something)

The participants are between the daughter and her mother. This conversation took place at home. The topic of this conversation was about looking for her father who was going out home. About $15.20 \mathrm{pm}$, the daughter looked for her father at home but her father was going out. Then, she asked her mother by using Javanese language "Abah nengdi, ma (Where is dad, mam?)'”. The mother replied her daughter's question "Aku gak ngerti Vi, mungkin diadah embahmu (I do not know Vi. Perhaps your dad is in your grandfather's house)". From this context of situation, the researcher identified that both participants employed the code mixing between Javanese and Banjarese language in their utterance. In the Banjarese words are used by her mother namely "diadah (a place)" is a Banjarese adverb showing in a certain place where someone is. And "ditakunakan (asked)" word is a Banjarese verb involving a prefix and suffix. The use of affixes in Banjarese language involves the root form with prefix, infix, and suffix, or combination between prefix with suffix for example ma-an $\rightarrow$ maunjunan (verb) in English 'fish', infix in ar like 'kajot $\rightarrow$ karojot (verb) in English 'pulse', and suffix in -i like hadangi in English 'wait for' (Hapip, 1981). In this case, ditakunakan (asked)" is a verb in a passive voice, which is indicated with a prefix "di and kan". It is used to ask for a question to someone in order to get a clear information. The relationship of them is a closer or more intimate relationship in the family.

b. Code switching

This data consists of the conversation between the husband and his wife. Her husband has stayed in this regency since he worked there and got a wife from a Banjarese ethnic. So, he has stayed in about 17 years.

Husband (Javanese) : Ding, hari ini aku balum gajihan, ada haja kalo duit? (My wife, today I have not got a salary yet, do you still have money?)

Wife (Banjarese) : Ada haja duit ka ai. Pabila gerang pian gajiahan? (Yes, I have. When will you get a salary)

Husband : Mungkin tanggal dua, sabar saja dulu. (It may be on the date of two, please be patient.)

Wife :Inggih. (Yes)

The topic was talking about the salary. In the discourse, the husband employed Banjarese language when he was talking to his wife. He spoke to his wife that he had not accepted the salary yet "Ding, hari ini aku balum gajihan, ada haja kalo duit? (My wife, today I have not got a salary yet, do you still have enough money ?)'"and asked his wife whether she had enough money or not. Then it was responded by his wife "Ada haja duit ka ai (Yes, I have)". After his wife said that sentence, then he switched his speech from Banjarese into Indonesian to go on the conversation. It indicated that he wanted to emphasize a message to his wife to be patient "Mungkin tanggal dua, sabar saja dulu (It may be on date two, please be patient)". This type of code switching is metaphorical code switching. Metaphorical code switching has a stylistic or textual function, such as to mark emphasis, to signal a change in tone from the very serious to the comic, to signal quotation, and to indicate the punch line of joke (Bloomfield and Gumperz in Downes, 1984). Moreover, they use two Banjarese words such as "ding (my wife) is used to call the wife and kak (my husband) is used to call her husband. Those words show love and affection symbols. In addition, Inggih (Yes) is more polite word that has a meaning for respecting old people or a beloved person. Therefore, this language choice is to show love and affection relationship between them.

\subsubsection{Neighborhood domain}

Neighborhood domain is between the close relationship of Javanese wife and a Banjarese neighbor and they usually talk about daily's activities. For example:

a. Code mixing

They are involved in the discourse.

Neighbor (Banjarese) : Bu, pian tadi datang dari mana? (Bu, where did you just come from?) 
Neighbor

: Seminggu sekali kah Bu? (Is it once a week, Bu?)

Wife

: Iih, tiap Jum'at (Yes, it is every friday)

The dialog was recorded on a conversation in her house. In this case, the neighbor asked her about her activity in code mixing (Banjarese and Indonesian). Actually they were different ethnic group background. In the dialog, the code mixing occurred when a neighbor visited her house in the afternoon and asked her " $B u$, pian tadi datang dari mana ?(Bu, where did you just come from?)" responded by her "Aku tadi datang dari yasinan di dekat SMP neto. (I just came from the association of reading Yassin Quran, near to SMP school)”.

The neighbor who mixes her language between Banjarese and Indonesian language in their utterance. Her neighbor used "pian (you) not ikam or nyawa (you)". "Pian (you)" word in Banjarese language means to respect and show more polite to older people. Otherwise, "ikam or nyawa (you)" word in Banjarese word is to show an equal status or talk to lower people. However, the use of "ikam or nyawa (you)" word is a separate dialect because in Banjarese language consists of two dialects, Kuala and Hulu dialects. Hapip (1975) notes that there are two dialects of Banjarese language happening in South Kalimantan province namely Kuala and Hulu. Those two dialects based on the differences of the use of certain vocabulary and vowel system. Nyawa (you) is in Kuala dialect, while ikam (you) is in Hulu dialect. However, the function is the same to address to a younger person, equal or lower status in the family or in the society. Moreover, a Javanese wife used "neto (that), iih (yes)" those Banjarese words are to emphasize on a clear explanation and direction. Their relationship is close between them and its function reflects the social meaning of showing respect.

b. Code switching

The datum is obtained in the kitchen room. The main participants of this conversation are among neighbors and Javanese wife. They have the same Javanese ethnic background.

Neighbor 1 (Javanese)

Wife (Javanese)

Neighbor 1

Wife

Neighbor 2 (Banjarese)
: Kulunuwon (Excuse me, anybody home)

Mlebu (Yes, please come in)

: Lagi ngapain ? Endi Jamal? (What are you doing? Where is Jamal?)

: Tahu keluar tadi, mungkin ditempat mbah Vivi (I do not know, perhaps he goes to Vivi's grandfather house)

: Sama siapa bu Vivi kesana ( With whom does Vivi go there?)

They talked about asking her husband who just went out. At the beginning, a neighbor addressed firstly by saying "Kulunuwon (Excuse me, anybody home)" as greeting in Javanese language to visit. And then replied by Javanese wife "Mlebu (Yes, please come in)". Here, "Kulunuwon (Excuse me, anybody home)" a word that used by her neighbor is from a Central Javanese dialect, which is considered as the most "refined" dialect. It was uttered because her neighbor was from the Central Java. On the contrary, "Mlebu (Yes, please come in)" the word that was replied by her using an Eastern Javanese dialect but there was no problem between them in communicating. The distinct dialect of Central and East Java the Javanese language remains the normal language of interaction in everyday life (Quinn: 2011). Both of words have dialectical differences in choice of words. This occurred because the Javanese wife came from the East Java. That was why they were different in using Javanese language to communicate.

The next dialog, the neighbor switched from Javanese to Indonesian language when he asked to her. The change of language or use of code switching above was accompanied with the change in the topic in which the change of language determined the situation. It meant that code switching from Javanese into Indonesian language might happen due to different dialect or ethnic. Trudgill (1992) argues that code switching is the process whereby bilinguals or bidialectals switch back and forth between one language or dialect and another within the same conversation. A speaker makes the switching to another language as a signal of group membership and shared ethnicity with an addressee primarily for social reasons (Holmes, 1992). Therefore, the code switching was classified into the type of metaphorical code switching.

Then the second question, the Javanese neighbor inserted a Javanese word to ask her "Endi Jamal? (Where is Jamal?)". And then the wife (javanese) replied her neighbor's question that she did not know "Tahu keluar tadi, mungkin ditempat embah Vivi (I do not know, perhaps he goes to Vivi's grandfather house". She also inserted a Javanese word "mbah (grandfather)" in responding her neighbor. In Saddhono \& Rohmadi's study revealed that " $m b a h$ " that is in Indonesian language means "kakek/nenek" (grandparents) whereas it had better use eyang rather than "mbah" (2014).

From the dialogue, the wife (Javanese) did not respond in Javanese language but she used Indonesian language. It was because the wife adapted herself to another participant or there was a new participant who joint the conversation. The new person had a distinct ethnic background between them, so that another participant could take part or understand what they were talking about. Thus, the function of this variety was to show solidarity. 


\subsubsection{Friendship domain}

In the friendship domain, the participants involved directly in the dialog and they recognize each other, also they have close relationship in their friendship. They can be a colleague, partner, best friend, and so on. The location of the discourse could take place anywhere or anytime as long as the topic of conversation is related to their friendship among them. The topic can be the common matters (the healthy condition, family's background, etc).

In this domain, there are three codes found namely a Banjarese code, Javanese code and mixing between Banjarese + Indonesian.

a. Code mixing

The researcher recorded their conversation when husband (Banjarese) was discussing to his friend.

Husband (Banjarese) $\quad$ : Sorang ini beliau ai calon do'akan ai (You know that I am a candidate, please pray me)

Friend (Banjarese) : : Ya bagus ai. Calon napa to? (That is good. What candidate?)

Husband (Banjarese) $\quad$ : Calon kepala desa disini (A candidate of village headman is here)

This conversation took place exactly at Kodim office. The participants were between husband (Banjarese) and his friend. This was just an informal occasion. The topic was talking about a candidate of village headman. Here, husband (Banjarese) talked to his friend about his willing to be a candidate of village headman. While his friend appreciated him by saying "Ya bagus ai. Calon napa to? (That is good. What candidate?)".

The participants employed the code mixing between Banjarese language and Indonesian language in their utterance. The words "sorang (I), and ai" (a stressing word). Husband (Banjarese) said firstly those words and then his friend also responds by mixing words such as Calon napa to? (What candidate?"). "Calon (candidate)" is an Indonesian word and "napa to" is Banjarese codes. Their relationship is solidarity and has an equal status. The word "sorang (I)" in informal Banjarese language means that they have an equal status in making friends in the society.

b. Code switching

There are three participants involved in the dialog. They are a Javanese husband, and his two friends. They were talking about informing registration of CPNS.

Husband (Javanese)

: Iih, mulai pendaftaran lo CPNS? (Well, does registration of CPNS begin today?)

Friend (Banjarese)

: Iih. Sampai tanggal empat, kada coba kah? (Yes,it does. It will be until February $4^{\text {th }}$. Do not you try this?)

Husband (Javanese)

: Koler sorang, kada koler anunya pang daftarnya pang, pacangan kada masuk jua. Sabtu ini penutupan. (I do not want to try this. I am sure that I am not accepted by them. On Saturday will be closed)

Friend (Javanese)

: Penutupan sabtu lah? (respond) (Will it be the closing of this on Saturday?)

Husband (Javanese)

: Tanggal papat jer (Yes, it will be until on the date of four)

In the dialog occurred in the market when the husband (Javanese) was selling the clothes in the clothing shop. He used Banjarese language to speak to his friend (Banjarese) because he wanted to adapt himself at the situation to the native for example "Iih, mulai pendaftaran lo CPNS ? (Well, does registration of CPNS begin today?)And responded in the same language "Iih...Sampai tanggal empat, kada coba kah? (Yes, it does. It will be until February $4^{\text {th }}$. Do not you try this?)". On the next dialog, Husband (Javanese) moved to another participant, to reply his question's friend at the same time because his friend heard what they were talking about. His friend had the same ethnic background with him, Javanese ethnic. Finally, he switched his code from Banjarese to Javanese.

Friend (Javanese)

\section{: Penutupan sabtu lah? (respond) (Will it be the closing of this on Saturday?)}

Husband (Javanese)

Iyo, tanggal papat (Yes, it will be until on date four).

The use of Banjarese to Javanese code is closely related to change another participant. As Sridard in Mckay said that people frequently switch from one language to another, when two or more languages exist in a community (1996). It is clear that the function of situational code switching in the friendship domain was to make an addressee specification. The first situational code switching is influenced by a change in situation, for instance a change in the setting, or topic of conversation and the attendance a new participant (Bloomfield and Gumperz in Downes, 1984). It means that the use of Banjarese+ Javanese language code switching is addressed to the typical speaker of the participants involved in the dialog. Then, the code switching employed by husband (Javanese) from Banjarese into Javanese language is social to make an intimate relationship or more casual relationship since Javanese language is more associated with an intimate style of a language than Banjarese language. This function reflects the social meaning of in- group solidarity, because they have the same ethnic group/ ethnicity.

\subsection{The Factors Influencing the Choice of Codes}

There are some factors influencing the use of codes. Fishman (1972) explained that the social factors namely age, sex, social status, level of education, and situational factors such as who speaks, what language, to whom, where, and when 
influencing the language use. Moreover, the preceding utterance also might influence the language use (Labov in Fishman, 1992).

\subsubsection{Situational Factor}

This situational factor relates to the cross married couples, Banjarese- Javanese ethnics in Tanah Laut regency South Kalimantan. This factor is always created by the participants at the home for instance the Javanese father or Javanese mother used Banjarese language when he or she communicated with the members of family at home. In this occasion, the participants are the Banjarese father, Banjarese mother, Javanese father, and Javanese mother as the speakers talk with their children (son or daughter). They mostly talk about daily's activities at home such as the father's advice to his daughter, learning problems at the school and so on. The following dialogue below play the role between the Javanese mother and her daughter. The conversation took place at home when the mother was asking her daughter who just went out suddenly.

$\begin{array}{ll}\text { Mother (Javanese) } & \text { : Kemana to, hah? (Where are you going, what?) } \\ \text { Daughter } & \text { : Kewadah kawan dulu. (I am going to go my friend's house) } \\ \text { Mother (Javanese) } & \text { : Lawaslah? (Is it a long time?) } \\ \text { Daughter } & \text { : Setumat haja. (No, just a moment) }\end{array}$

The participants used Banjarese language in their conversation. The situational factor between mother and her daughter influenced this choice of code. It referred in a relaxed situation at home, then the mother asked "Lawaslah? (Is it a long time?)" and replied honestly by her daughter that she was not a long time to go out "Setumat haja. (No, just a moment)". The underline particle words lah and haja emphasize a question form (lah) and giving a true statement (haja). Actually, her mother is a Javanese ethnic. But, in this scene she employs Banjarese language to show the intimacy between them.

\subsubsection{The Environment (neighborhood)}

The discourse happened in the Javanese mother and Banjarese neighbor, they used to talk about daily's activities outside the house or in surroundings such as the neighbor's curiosity of her activity, telling their children's condition and so on. When they met at the same or different ethnic in the neighborhood, he/ she sometimes mixed or switched his/ her code. Holmes stated that there are relevant social factors in accounting for particular variety used (1992). Here is examples based on the environmental factor. Both participants have the same Javanese ethnic background.

$\begin{array}{ll}\text { The neighbor (Javanese) } & : \text { Kulunuwon (Excuse me, anybody home) } \\ \text { Wife (Javanese) } & \text { Mlebu (Yes, please come in) } \\ \text { The neighbor } & : \text { Lagi ngpain? Endi Jamal? (What are you doing? Where is Jamal?) }\end{array}$

In this case, the neighbor greeted a wife (Javanese) "Kulunuwon (Excuse me, anybody home)" by using a Javanese word. Then, in the next dialog he switched his speech from Javanese into informal Indonesian language such as Lagi ngpain? Endi Jamal? (What are you doing? Where is Jamal?). It meant that the occurrence of code switching changed the situation closer between them. The use of "Kulunuwon (Excuse me, anybody home)"word in Javanese language has a high language/ function that is called "karma" or high Javanese because in Javanese language is classified into three levels namely low Javanese (ngoko), high Javanese, (krama), and augmented respect vocabulary (Quinn, 2011). It is used to address someone in visiting to the house and in this case is also influenced by the environmental factor which forms it because both of them live in Javanese community.

\subsubsection{Relative Status}

In relative status, there are similar characteristics to the Banjarese dialects employed by one of the participants like " $n a h$, and lah". The words are particle forms stressing to a question or truly statement and followed by a high intention. Here are the following examples.

This datum consists of the conversation between their children (sister-younger sister) and their Javanese grandmother.

Younger sister : Minta, ka (Please give me, sister)

Sister : Koler (No.) (Leaving her younger sister, suddenly her grandmother summoned and asked her)

Grandmother (Javanese) : Eeeh, duit tadi dimana? Nyawa ambil tadi lah? (Where is the money? Have you taken it?)

Sister : Nih duitnya (Here is the money) (Showing the money to her grandmother)

Grandmother : Nah, seribuan lah ( Well, it is a thousand)

The setting of the conversation is at the home in the afternoon. Their discourse was asking for the food and money. In the conversation, the sister spoke to her younger sister in Banjarese language when she did not want to give the food "Koler (No) (Leaving her younger sister, suddenly her grandmother summoned and asked her)". Then, her grandmother summoned and asked her by using code mixing, Indonesian and Banjarese language Eeeh, duit tadi mana? 
Nyawa ambil tadi lah? (Where is the money? Have you taken it?) And replied by the sister using Indonesian language "Nih duitnya (Here is the money)".

Thus, the phenomenon of situational code switching occured in which there were the changes another participant and the topic. That was the strategy used by the sister because her grandmother came from the Javanese ethnic and is not familiar with Banjarese language. However, there were two words inserted by the grandmother namely nyawa (you), and lah (a particle word). Nyawa (you) word is a Kuala Banjarese dialect is used in Tanah Laut regency. In Kawi's study identified the dialects based on regencies in South Kalimantan province, mostly Kuala dialect applied in Tanah Laut regency, Banjarmasin city, Banjar regency, Kotabaru regency, and Batola regency, while Hulu dialect happens in Tabalong, Hulu Sungai Utara regency, Hulu Sungai Tengah regency, Hulu Sungai Selatan, and Tapin regency (1977). The other side, from the dialog there is any lah (particle word) in Banjarese language emphasized on a question form and followed a high intonation in the conversation.

\subsubsection{Ethnicity}

All actors had the same ethnic background such as between a Banjarese mother and her Banjarese neighbor, a Javanese father and his Javanese aunt, Javanese mother's son and his Javanese friend. Thus, there are similar characteristics of the whole data. They are nih, kah, and loh (Banjarese). Those words emerge to stress a question or true statement. Those are usually followed by a high intonation. Here are the following examples.

Neighbor (Banjarese)

Wife (Banjarese)

Neighbor

\section{: Kemanaan urangnya nih? (Where are your children?)}

:Tinggalkan setumat haja kadapur hilangan urangnya, kemanakah urangnya tadi? (While I just left them for a just moment to the kitchen, they have gone. I do not know where they are now?)

: Iiih (Yes. I see)

The neighbor was involved in this conversation asking her children who went suddenly without being known by wife (Banjarese). They used Banjarese language to communicate between them. It indicated that they had the same ethnic group background, Banjarese ethnic, the use of Banjarese language was very appropriate. Thus, this choice of code was mainly influenced by their ethnicity.

\section{Conclusion}

Codes used by the cross- married couples, Banjarese- Javanese ethnic in Tanah Laut regency South Kalimantan province, Indonesia have varied codes in different domains namely family, neighborhood, friendship domains. There are code mixing and code switching found in those domains. For example, the Javanese wife or husband sometimes mixes their speech between Banjarese and Indonesian or Banjarese and Javanese. This code mixing is done by Javanese father/mother to their children, the Javanese grandmother to her grandchild and the Javanese aunt to her niece. Code mixing between Banjarese+ Indonesian is chosen by them when they communicate or adapt themselves to other Banjarese participants or other participants. In addition, code mixing between Javanese+ Banjarese is also applied by the Javanese husband or wife when they try to socialize or teach their indigenous language to the member of family or relatives. While, code switching from Banjarese into Indonesian is used by the participants when there is another participant or a new participant that has the different ethnic to the speaker. Meanwhile, there are four factors influencing the choice of codes in the intercultural marriage, Banjarese- Javanese ethnics group in Tanah Laut regency South Kalimantan province namely situational factor, the environment (neighborhood), relative status, and ethnicity.

\section{Rreferences}

Chaika, E. (1998). Language the social mirror. Massachusetts USA: Newbury House Publishers Inc.

Downes, W. (1984). Language and society. London: Fontana Paperbacks.

Fink, A. (1995). How to sample in survey. California: Sage Publications, Inc.

Fishman, J. A. (1972). The sociology of language. Rowley Massachusetts: Newberry House Publisher.

Giglioli, P.P. (1974). Sociolinguistics. UK: Longman Company.

Hapip, A. J. (1975). Struktur bahasa banjar Kuala. Jakarta: Pusat Pengembangan dan Pembinaan Bahasa, Departemen Pendidikan dan Kebudayaan.

Hapip, A. J. (1981). Struktur bahasa banjar. Jakarta: Pusat Pengembangan dan Pembinaan Bahasa, Departemen Pendidikan dan Kebudayaan.

Harding, E., and Riley, P. (1986). The bilingual family. Cambridge: Cambridge University Press.

Holmes, J. (1992). Introduction to sociolinguistics. London: Longman.

Hymes, D. (1984). The ethnography of communication: an introduction. New York: Muriel Saville Press.

Kawi, D. (1977). Geograpi dialek kotamadya Banjarmasin. Jakarta: Pusat Pengembangan dan Pembinaan Bahasa, Departemen Pendidikan dan Kebudayaan. 
McKay, S.L., and Nancy, H.H. (1996). Sociolinguistics and language teaching. Cambridge: Cambridge University Press.

Marjohan, A. (1976). Sosiolinguistik. Yogyakarta: Kanisius press.

Moleong, L.J. (1993). Metodologi penelitian kualitatif. Bandung: Remaja Rosdakarya.

Quinn, G. (2011). Teaching Javanese respect usage to foreign learners. Electronic Journal of Foreign Language Teaching, 8, pp. 362-370.

Saddhono, K., \& Rohmadi, M. (2014). A sociolinguistics study on the use of the Javanese language in the learning process in primary schools in Surakarta, Central Java, Indonesia. International Education Studies, 7(6), 2014.

Sumarsih, et al. (2014). Code switching and code mixing in Indonesia: study in sociolinguistics. English Language and Literature Studies, 4(1), 2014.

Surakhmad, W. (1994). Pengantar penelitian ilmiah: dasar, metode, \& teknik. Bandung: Penerbit Tarsito.

Trudgill, P. (1992). Introducing language and society. London: Penguin Books Ltd.

Wardhaugh, R. (1998). Introduction to sociolinguistics. Massachusetts: Newbury House Publishers Inc. 